\title{
PERBEDAAN KEMAMPUAN MENULIS BERITA SISWA KELAS VII SMPN 3 PARIAMAN DENGAN MEDIA GAMBAR DAN OBJEK LANGSUNG
}

\author{
Astuti Samosir \\ astutisamosir77@gmail.com
}

\author{
Prodi Pendidikan Bahasa Indonesia, Fakultas Bahasa dan Seni \\ Universitas Indraprasta PGRI
}

\begin{abstract}
Abstrak
Penelitian ini bertujuan untuk: (1) mendeskripsikan kemampuan menulis berita siswa kelas VII SMPN 3 Pariaman dengan Media Gambar. (2) mendeskripsikan kemampuan menulis berita siswa kelas VII SMPN 3 Pariaman dengan objek langsung. (3) mendeskripsikan perbedaan kemampuan menulis berita siswa kelas VII SMPN 3 Pariaman, dengan media gambar dan objek langsung. Penelitian ini merupakan penelitian eksperimen semu (quasi experimental research). Berdasarkan hasil analisis data dan pembahasan diperoleh kesimpulan sebagai berikut. Pertama, kemampuan siswa kelas eksperimen dengan menggunakan objek langsung berada pada kualifikasi baik (B) dengan rata-rata hitung 81,11. Kedua, kemampuan siswa kelas kontrol dengan menggunakan media gambar berada pada kualifikasi cukup (C) dengan rata-rata hitung 76. Ketiga, setelah dilakukan uji-t diperoleh $t_{\text {hitung }}=1,96$ dan $t_{\text {tabel }}=1,67$ yaitu $t_{h}>t_{t}$, maka $\mathrm{H}_{1}$ diterima. Jadi, terdapat perbedaan kemampuan siswa kelas VII SMPN 3 Pariaman dengan objek langsung dan media gambar.
\end{abstract}

\begin{abstract}
The purpose of this study is: (1) describe the ability to write news class VII SMPN 3 Pariaman with media images. (2) describe the ability to write news with a direct object. (3) describe the difference in the ability to write news class VII SMPN 3 Pariaman with media images and object directly. This type of research is quasi experimental research.. The results of this study. First, the ability to write an experimental class by using the object directly is in good qualification $(81,11)$. Second, the ability to write a control class student by using the image in sufficient qualification. Third, obtained $t_{h}$ $=1,96$ dan $t_{t=}$ 1,67 yaitu $t_{h}>t_{t, \text { then }} H_{1}$ accepted. There are differences in the ability write news class VII SMPN 3 Pariaman with direct objects and media images.

Kata Kunci: menulis berita, media gambar, objek langsung.
\end{abstract}

\section{PENDAHULUAN}

Pembelajaran bahasa
Indonesia bertujuan untuk meningkatkan kompetensi peserta didik dalam berkomunikasi secara baik secara lisan dan tulisan. Pelaksanaan pembelajaran bahasa Indonesia menuntut guru mampu menguasai 4 aspek kebahasaan seperti: mendengarkan/menyimak, berbicara, membaca, dan menulis. Kemampuan menulis merupakan aspek kemampuan dalam berbahasa. Kemampuan mendengarkan dalam pembelajaran bahasa Indonesia juga sangat berperan penting untuk menimbulkan gagasan dalam menulis, karena dengan kemampuan menulis, siswa mampu menuangkan ide, gagasan, pikiran, perasaan, 112 | Jurnal Kredo Vol. 2 No. 1 Oktober 2018 wawasan, dan pengetahuan yang mereka miliki melalui mendengarkan suatu peristiwa atau kejadian menjadi sebuah karangan.

Kemampuan/keterampilan menulis yang harus dikuasai oleh siswa ialah menulis berita. Menulis berita diartikan sebagai kegiatan menuangkan fakta atau ide berkenaan dengan kejadian saat ini. Pembelajaran menulis berita di SMP masih mengalami permasalahan. Permasalahan pengajaran menulis berita disebabkan oleh beberapa faktor, diantaranya sebagai berikut. Pertama, pengelolaan jam pelajaran harus disesuaikan dengan materi pembelajaran yang harus dicapai oleh guru dan peserta didik. Guru lebih fokus terhadap penyelesaian materi pembelajaran tanpa 
memperhatikan pengaplikasian materi pembelajaran. Kedua, siswa tidak mampu menemukan ide dan memulai menulis berita. Siswa masih ragu dalam memulai menulis berita dan siswa tidak mampu menentukan jenis berita yang akan mereka tulis. Ketiga, hasil menulis siswa kurang mendapatkan apresiasi dari guru. Pada umumnya, tulisan siswa hanya mendapatkan nilai berupa angka tanpa adanya apresiasi berupa pempublikasian hasil menulis siswa dalam bentuk koran sederhana atau majalah sederhana.

Seperti halnya pendapat Hermawan, dkk (2004: 59) yang menjelaskan bahwa faktor yang paling memengaruhi dalam pembelajaran menulis yaitu semangat menulis dalam diri siswa dan juga guru yang mengajarnya. Artinya bahwa dua unsur utama ini sangat menentukan pembelajaran menulis. Faktor siswa yang berarti bahwa siswa harus memiliki motivasi yang kuat dalam belajar menulis. Sedagkan faktor guru, berarti guru harus lebih kreatif dalam pembelajaran.

Berdasarkan wawancara penulis secara informal dengan guru bahasa Indonesia yaitu Mardiana, S.Pd di SMPN 3 Pariaman disimpulkan bahwa keterampilan menulis berita sulit untuk diajarkan karena siswa pada umumnya mengalami kesulitan untuk memulai menulis berita, siswa menganggap menulis berita sangat sulit dan membosankan. Paradigma buruk dari siswa berkenaan dengan menulis berita, semakin menyulitkan guru dalam pembelajaran menulis berita.

$$
\text { Tindakan untuk }
$$

menyelesaikan problematika seperti yang telah dijabarkan di atas, maka perlu diadakan tindakan nyata melalui penggunaan media pembelajaran. Media pembelajaran yang dapat diterapkan dalam menulis berita yaitu media gambar dan objek langsung. Media gambar bertujuan agar siswa mampu menemukan ide atau gagasan melalui gambar dalam menulis berita. Melalui gambar maka siswa dapat menulis berita kejadian di sekitar mereka, dapat dijadikan sebuah berita yang baik dan sesuai dengan unsur-unsur berita. Selain media gambar, objek langsung juga dapat membantu siswa dalam menulis berita. Objek langsung dalam pembelajaran berita dapat digunakan dengan mendayagunakan lingkungan sekitar siswa. Dengan objek langsung siswa dapat mengamati suatu peristiwa secara langsung.

Tujuan dilaksanakannya penelitian ini adalah untuk: (1) mendeskripsikan kemampuan menulis berita siswa kelas VII SMPN 3 Pariaman dengan media gambar, (2) mendeskripsikan kemampuan menulis berita siswa kelas VII SMPN 3 Pariaman dengan objek langsung, (3) mendeskripsikan perbedaan kemampuan menulis berita siswa kelas VII SMPN 3 Pariaman, dengan media gambar dan objek langsung.

\section{KAJIAN TEORI}

Menulis merupakan kegiatan menuangkan lambang-lambang grafik yang mendeskripsikan suatu konsep kebahasaan yang dapat dengan mudah dipahami, sehingga pembaca mampu membaca lambanglambang grafik tersebut (Tarigan, 2008:22), Yurniwati (2010: 174) juga menyatakan menulis bukan hanya sekedar melambangkan pola bahasa yang terucapkan, menulis merupakan suatu wadah yang dapat 
mengkomunikasikan suatu pemikiran, sarana dalam berekspresi, sarana untuk beradaptasi, dan alat untuk kontrol sosial, melalui suatu tulisan, pembaca akan mengetahui jalan dan hasil pemikiran seseorang. Sehingga menulis menjadi sebuah kegiatan dalam mengungkapkan suatu ide/pemikiran kedalam lambang-lambang tulisan dengan memerhatikan tiga aspek utama penulisan (Semi 2007:14). Sehingga, dapat disimpulkan bahwa menulis merupakan proses kreatif yang menggambarkan suatu bahasa berupa gagasan dalam lambang-lambang tulisan. Melalui suatu tulisan seseorang, dapat mengkomunikasikan ide dan gagasan. Ide dan gagasan dapat dikomunikasikan melalui tulisantulisan yang memiliki makna.

Semi (2009: 17-18)

menyatakan lima tujuan menulis adalah: memberikan arahan, mendeskripsikan sesuatu, menceritakan kejadian, meringkas/merangkum, meyakinkan. Salah satu jenis kegiatan menulis yaitu menulis berita. Menurut Maulsby (dalam Assegaf, 1982: 24), berita merupakan suatu ungkapan fakta-fakta yang mampu mengubah konsep pemikiran para pembaca berita. Lalu, Hikmat dan Kusumaningrat (2005: 40) juga menyatakan bahwa berita merupakan informasi terbaru berkenaan dengan fakta dan opini. Assegaf (1982: 24) mendefinisikan berita adalah suatu tulisan yang memuat fakta/opini tentang saat ini, kemudian diseleksi oleh staf redaksi berdasarkan keadaan masyarakat yang dapat memuat humor, emosi, dan ketegangan.

Hikmat dan Kusumaningrat (2005:153) membagi berita menjadi lima sebagai berikut: straight news (berita langsung), depth news (berita mendalam), dikembangkan dengan pendalaman hal-hal yang ada di bawah suatu permukaan. investigation news (berita yang dikembangkan berdasarkan penelitian atau penyelidikan dari berbagai sumber). interpretative news (berita yang dikembangkan dengan pendapat atau penelitian penulisnya/reporter). opinion news (berita mengenai pendapat seseorang).

Penulisan berita dengan gaya piramida terbalik bertujuan untuk memberikan kemudahan bagi pembaca dalam memperoleh informasi/kejadian terkini. Judul berita (headline) memiliki peran sebagai langkah cepat pembaca untuk mengetahui kejadian terbaru. Setelah judul berita, dijumpai teras berita, selanjutnya isi berita yang memuat $(5 \mathrm{~W}+1 \mathrm{H})$.

Teras berita seharusnya memuat fakta penting yang diberitakan sehingga pembaca tertarik untuk membaca secara keseluruhan. Teras berita memuat $5 \mathrm{~W}+1 \mathrm{H}$ (What, Who, Where, Why, How). Macam-macam teras berita sebagai berikut. Pertama, teras berita apa (what) Contoh: Pembukaan CPNS 2018 telah dibuka melalui akun resmi sscn.bkn.go.id. Kedua, Teras berita siapa (who). Contoh: Presiden Jokowi mengadakan kunjungan selama 5 hari ke Korea Selatan. Ketiga, teras berita di mana (where). Contoh: Telah terjadi gempa di Lombok. Keempat, Teras berita kapan (when). Contoh: kemarin siang, Presiden Jokowi telah tiba di tanah air setelah mengadakan kunjungan kenegaraan. Kelima, Teras berita mengapa atau bagaimana (why atau how). Contoh: 
untuk meningkatkan penghasilan daerah, kemarin pagi diadakan sosialisasi terhadap pemerintah daerah. Selain teras berita dikembangkan dengan rumus $5 \mathrm{~W}+$ $1 \mathrm{H}$ oleh para wartawan dan ahli-ahli jurnalistik, juga dikembangkan macam-macam teras berita di luar rumus $5 \mathrm{~W}+1 \mathrm{H}$. Macam-macam teras berita lain di luar rumus $5 \mathrm{~W}+1 \mathrm{H}$ adalah exclamation lead (teras berita yang menjerit), quotation lead (teras berita kutipan), contras lead (teras berita kontras).

Menurut Assegaf (1982: 54), lima teknik menulis tubuh berita yaitu: laporan berita bersifat menyeluruh, tertib dan teratur sesuai gaya menulis berita, sesuai dengan gaya bahasa dan tata bahasa yang berlaku saat ini, ekonomi kata harus diterapkan dan gaya penulisan haruslah tetap hidup. Sedangkan, Hikmat dan Kusumaningrat (2005: 153-156) menyatakan bahwa beberapa hal yang harus dipatuhi dalam menulis berita yaitu: pertama, spesifik. Misalnya: "Sejumlah Negara turut serta mensukseskan ASIAN Games" kurang spesifik dibandingkan " 20 Negara turut serta mensukseskan ASIAN Games". kedua, kalimat aktif dan pasif. Contoh: "Bola itu ditendang oleh Kurniawan" kurang memberi tekanan dan jika ditulis "Kurniawan menendang bola itu" lebih member tekanan. ketiga, kalimat harus pendek. keempat, variasikan kalimat. kelima, alinea harus pendek. keenam, sebutkan identitas orang. ketujuh, tanggal kejadian. kedelapan, tata bahasa dan ejaan.

Persyaratan dalam menulis berita yaitu $5 \mathrm{~W}+1 \mathrm{H}$ (What, Who, Where, Why, When dan How). Menurut Hikmat dan Purnama Kusumaningrat (2005: 48-58), unsur- unsur layaknya suatu berita sebagai berikut: berita harus akurat, berita harus lengkap, adil, dan berimbang, berita harus ringkas dan jelas dan berita harus objektif.

Sanjaya (2008: 163), menyatakan bahwa media tidak hanya bahan saja, tetapi hal lainnya yang dapat memungkinkan siswa memperoleh ilmu pengetahuan. Berdasarkan teori para ahli di atas, maka disimpulkan bahwa media adalah segala sesuatu yang dipakai untuk menyampaikan pesan atau informasi yang memungkinkan siswa dapat memperoleh pengetahuan yang dapat merangsang pikiran, perasaan, perhatian, dan minat. Berdasarkan sifatnya, media diklasifikasikan ke dalam media auditif, media visual, media audiovisual. Media gambar digolongkan menjadi media visual. Karena, media visual merupakan media yang dapat dilihat saja, tetapi tidak mengandung unsur suara (Sanjaya, 2008: 172).

Keunggulan media gambar menurut Sadiman (2006: 40) sebagai berikut. Pertama, gambar bersifat konkrit, jadi media gambar lebih mampu menunjukkan suatu pokok permasalahan. Kedua, penggunaan media gambar dapat mengatasi persoalan batasan ruang dan waktu. Ketiga, media gambar mampu mengatasi keterbatasan pengamatan. Keempat, media gambar mampu mendeskripsikan secara jelas suatu masalah dalam segala bidang. Kelima, media gambar lebih murah secara harga selain itu juga mudah didapatkan dan dugunakan. Cara menerapkan media gambar berseri adalah pertama guru menyampaikan pengantar, lalu guru menempelkan beberapa gambar di depan kelas, setelah siswa melihat gambar tersebut, siswa mulai 
mengidentifikasikan gambar, dari identifikasi itu siswa membuat tulisan secara runtut dan logis, guru bertanya alasan siswa tentang alasan tulisan yang dibuatnya, guru merefleksikan pembelajaran.

Selain media grafis, guru dapat menggunakan lingkungan sebagai media pembelajaran (Sudjana dan Ibrahim, 2010: 208). Guru dan siswa mengamati kemudian mempelajari keadaan atau situasi di luar kelas dengan mengajarkan serta memperkenalkan para siswa terhadap lingkungan yang terbaru untuk dipelajari. Dengan lingkungan sebagai objek langsung pembelajaran menulis berita semakin bermakna karena siswa dihadapkan dengan peristiwa sebenarnya. Kelebihan lingkungan (objek langsung) sebagai media pembelajaran sebagai berikut. Pertama, kegiatan proses belajar lebih menarik dan tidak membosankan bagi siswa. Kedua, pembelajaran lebih bermutu karena siswa dihadapkan dengan situasi sebenarnya. Ketiga, kegiatan proses belajar siswa lebih aktif karena dapat dilakukan dengan mengamati/mengobservasi dan mewawancarai. Keempat. sumber belajar menjadi lebih luas sebab lingkungan yang dipelajari beraneka ragam.

\section{METODE PENELITIAN}

Jenis penelitian yang dipakai ialah penelitian eksperimen semu (quasi experimental research). Menurut Suryabrata (2004: 92), eksperimen semu (quasi experimental research) bertujuan untuk mendapatkan informasi yang merupakan dugaan bagi informasi yang diperoleh dengan memakai eksperimen yang sebenarnya dalam keadaan yang tidak memungkinkan untuk mengontrol dan memanipulasikan semua variabel yang relevan atau sesuai. Rancangan yang digunakan ialah the static group: randomized control group only design.

Metode penelitian yang digunakan adalah metode deskriptif karena penelitian ini bertujuan untuk menggambarkan data berkenaan dengan perbandingan kemampuan menulis berita siswa kelas VII SMPN Pariaman dengan media gambar dan objek langsung maka metode penelitian ini adalah metode deskriptif.

Tiga variabel yang terdapat dalam penelitian ini Pertama, variabel bebas yaitu objek langsung dan media gambar. Kedua, variabel terikat ialah menulis berita siswa kelas VII SMPN 3 Pariaman. Ketiga, variabel kontrol yaitu siswa kelas VII SMPN 3 Pariaman, materi pembelajaran, dan media pembelajaran. Data hasil penelitian ini adalah tes kemampuan menulis berita. Data penelitian ini adalah hasil belajar siswa dalam menulis berita dengan media gambar dan hasil menulis berita dengan objek langsung.

Tes unjuk kerja dengan menulis berita merupakan instrumen yang digunakan dalam penelitian ini.Tes dilakukan dua kali yaitu tes kemampuan menulis berita dengan teknik gambar di kelas kontrol dan kelas eksperimen dengan teknik objek langsung.

Langkah yang dilakukan oleh peneliti sebelum pengumpulan data dilakukan yakni memberikan materi pembelajaran di kelas eksperimen dan di kelas kontrol. Setelah pembelajaran di kelas eksperimen 
dan kelas kontrol dilakukan, maka penulis akan melakukan pengumpulan data sebagai berikut. Pengumpulan data dilakukan dengan memberikan tes menulis berita. Berita yang ditulis oleh siswa minimal dua paragraf. Pada kelas kontrol, penulis memberikan tes menulis berita dengan media gambar. Sedangkan pada kelas eksperimen, penulis memberikan tes menulis berita dengan objek langsung sebagai media pembelajaran. Tema berita tidak ditentukan atau siswa bebas menulis jenis-jenis berita yang akan mereka tulis. Setelah siswa selesai menulis berita, hasilnya dikumpul dan diperiksa sesuai dengan indikator yang diteliti.

Penganalisisan data penelitian ini menggunakan sistematika sebagai berikut. Pertama, membaca dan memahami berita yang telah ditulis oleh siswa pada lembar unjuk kerja. Kedua, mengoreksi hasil unjuk kerja berupa menulis berita sesuai dengan indikator yang dinilai yaitu struktur berita, unsur-unsur berita, unsur kebahasaan (Ejaan dan Tanda Baca) dengan menggunakan rubrik penilaian.

Tabel 1

Format Penilaian Kemampuan Menulis Berita

\begin{tabular}{|c|c|c|c|c|c|c|c|c|c|c|c|c|c|}
\hline \multirow{3}{*}{$\begin{array}{l}\mathrm{K} \\
\mathrm{S}\end{array}$} & \multicolumn{12}{|c|}{ Indikator/Aspek yang dinilai } & \multirow{3}{*}{$\begin{array}{l}\mathrm{S} \\
\text { ko } \\
\mathrm{r} \\
\mathrm{T} \\
\text { ot } \\
\mathrm{al} \\
12\end{array}$} \\
\hline & \multicolumn{4}{|c|}{$\begin{array}{l}\text { Struktur } \\
\text { Berita (SB) }\end{array}$} & \multicolumn{4}{|c|}{$\begin{array}{l}\text { Unsur- } \\
\text { unsur } \\
\text { Berita } \\
\text { (UB) }\end{array}$} & \multicolumn{4}{|c|}{$\begin{array}{l}\text { Unsur } \\
\text { Kebahasaa } \\
\text { n (EYD, } \\
\text { TB) }\end{array}$} & \\
\hline & 1 & 2 & 3 & 4 & 1 & 2 & 3 & 4 & 1 & 2 & 3 & 4 & \\
\hline & & & & & & & & & & & & & \\
\hline & & & & & & & & & & & & & \\
\hline & & & & & & & & & & & & & \\
\hline & & & & & & & & & & & & & \\
\hline
\end{tabular}

Keterangan:

Indikator I (Struktur Berita) diberikan skor 4 apabila terdapat judul berita, teras berita, isi berita secara lengkap dan benar. Skor 3 diberikan apabila judul berita, teras berita, isi berita secara lengkap dan terdapat beberapa kesalahan. Skor 2 diberikan apabila tidak memuat satu struktur berita. Skor 1 diberikan apabila teras berita hanya memuat satu struktur berita.

Indikator II (Unsur-unsur Berita) penilaian diberikan skor 4 apabila memuat 4 unsur berita (contoh: $3 \mathrm{~W}+1 \mathrm{H}$ ). Diberikan skor 3 apabila terdapat 3 unsur berita (contoh: $2 \mathrm{~W}+1 \mathrm{H}$ ). Diberikan skor 2 apabila terdapat 2 unsur berita (contoh: 2W). Diberikan skor 1 apabila terdapat 1 unsur berita (contoh: 1W).

Indikator III (Unsur Kebahasaan) penilaian diberikan skor 4 apabila berita yang ditulis sudah sesuai dengan ejaan dan tanda baca. Diberikan skor 3 apabila berita yang ditulis sesuai dengan ejaan tetapi terdapat beberapa kesalahan dalam tanda baca. Diberikan skor 2 apabila berita yang ditulis terdapat kesalahan dalam ejaan dan tanda baca. Diberikan skor 1 apabila berita yang ditulis banyak terdapat kesalahan dalam tanda baca dan ejaan.

Ketiga, mengubah skor mentah menjadi nilai. Menurut Abdurahman dan Ratna (2003: 264), penghitungan hasil atau nilai berdasarkan perhitungan persentase dengan rumus berikut ini:

$$
\mathrm{N}=\frac{s \pi}{s j} \times \mathrm{S}_{\mathrm{Max}}
$$

Keterangan:

$\mathrm{N}$ =tingkat penguasaan

$\mathrm{SM}=$ skor yang diperoleh

SI =skor yang harus dicapai dalm suatu tes

$\mathrm{S}_{\mathrm{Max}}=$ skala yang digunkan 
Keempat, penentuan nilai rata-rata hitung kemampuan menulis berita, Burhan (2001: 360) menyatakan bahwa untuk menghitung nilai rata-rata hitung bisa memakai rumus sebagai berikut.

$$
\bar{X}=\frac{\sum \mathrm{x}}{\mathrm{N}}
$$

Keterangan:

$\bar{X}=$ nilai rata-rata

$\sum \mathrm{X}=$ hasil perkalian frekuensi dan skor

$\mathrm{N}=$ jumlah siswa

Kelima, mengklasifikasikan

(1) keterampilan menulis berita siswa kelas VII SMPN 3 Pariaman dengan teknik gambar berdasarkan indikator yang dinilai, dan (2) keterampilan menulis berita siswa kelas VII SMPN 3 Pariaman dengan teknik objek langsung berdasarkan indikator yang dinilai berdasarkan skala 10 berikut ini.

Ketujuh, melakukan uji hipotesis. Sebelum dilakukan uji hipotesis, terlebih dahulu dilaksanakan uji homogenitas dan uji normalitas dengan liliefors (Sudjana 2005:4 66-468) rumus yang digunakan untuk menguji hipotesis adalah:

$$
\begin{aligned}
& \mathrm{t}=\frac{\overline{X_{1}}-\overline{X_{2}}}{\sqrt[s]{\frac{1}{n+1}+\frac{1}{n \bar{s}}}} \\
& \text { dengan } \mathrm{S}^{2}=\frac{(n 1-1) s_{1}^{2}+(n 2-1) s_{2}^{2}}{n 1+n 2-2}
\end{aligned}
$$

Keterangan:

$$
\begin{aligned}
& \overline{X 1}=\text { rata-rata hitung variabel } \mathrm{x} \\
& \text { (kelas eksperimen) } \\
& \overline{X 2}=\text { rata-rata hitung variabel } \mathrm{y} \\
& \text { (kelas kontrol) } \\
& \overline{X 1} \quad=\text { rata-rata hitung variabel } s 1 \\
& \mathrm{~S}_{1} \quad=\mathrm{SD} \text { variabel } \mathrm{x} \text { (kelas } \\
& \text { eksperimen } \\
& \mathrm{S} 2=\mathrm{SD} \text { variabel } \mathrm{y} \text { (kelas } \\
& \text { kontrol) } \\
& \mathrm{n} 1=\text { Jumlah variabel } \mathrm{x} \text { (kelas } \\
& \text { eksperimen) } \\
& \mathrm{n} 1=\text { Jumlah variabel } \mathrm{y} \text { (kelas } \\
& \text { kontrol) } \\
& \mathrm{S}=\text { Standar deviasi gabungan }
\end{aligned}
$$

118 | Jurnal Kredo

Vol. 2 No. 1 Oktober 2018
Berdasarkan hasil yang didapat dengan menggunakan rumus uji t, selanjutnya diinterpretasikan ke dalam $\mathrm{t}$ tabel dengan derajat kebebasan $(\mathrm{dk})=\mathrm{n}_{1}+\mathrm{n}_{2}-2$ pada taraf kepercayaan 95\%. Jika t hitung lebih besar dari pada t tabel, dapat diinterpretasikan bahwa adanya perbedaan yang signifikan antara variabel $\mathrm{VII}_{1}$ dan $\mathrm{VII}_{4}$. Kedelapan, membahas hasil analisis dan menyimpulkan hasil pembahasan.

\section{HASIL DAN PEMBAHASAN}

Indikator penilaian terhadap kemampuan menulis berita mencakup 3 hal sebagai berikut: teras berita, unsur-unsur berita, unsur kebahasaan. Gambaran kemampuan siswa dalam menulis berita dengan memakai objek langsung sebagai media pembelajaran untuk setiap indikator diuraikan sebagai berikut.

a. Kemampuan Siswa Kelas VII SMPN 3 Pariaman dalam Menulis Berita dengan Menggunakan Objek Langsung dan Media Gambar Indikator I (Struktur Berita)

$$
\begin{aligned}
& \text { persentase. } \\
& \qquad \begin{aligned}
\mathrm{N}(01)= & \frac{5 \pi}{53} \times 5 \text { Max } \\
& =\frac{4}{4} \times 100 \% \\
& =100
\end{aligned}
\end{aligned}
$$

Berikut ini diuraikan contoh mencari nilai dengan rumus

Hasil analisis dan nilai ratarata tiap sampel dalam indikator I (struktur berita) dimasukkan ke dalam tabel konveksi skala 10. Pada tabel di bawah ini digambarkan berkenaan dengan kemampuan siswa dalam menulis berita yang berkaitan dengan struktur berita.

Tabel 2 
Kemampuan Siswa Kelas VII1 SMPN 3 Pariaman dalam Menulis Berita dengan Menggunakan Objek Langsung Indikator I (Struktur Berita)

\begin{tabular}{|c|c|c|c|c|}
\hline $\begin{array}{l}\mathrm{N} \\
\mathrm{O}\end{array}$ & $\begin{array}{c}\text { Tingkat } \\
\text { Penguasaa } \\
n\end{array}$ & Kualifikasi & $\begin{array}{c}\text { Frekuens } \\
\text { i }\end{array}$ & $\begin{array}{l}\text { Persent } \\
\text { ase }\end{array}$ \\
\hline 1 & $96-100 \%$ & Sempurna & 14 & 46,67 \\
\hline 2 & $86-95 \%$ & Baik sekali & 0 & 0 \\
\hline 3 & $76-85 \%$ & Baik & 0 & 0 \\
\hline 4 & $66-75 \%$ & Cukup & 15 & 50 \\
\hline 5 & $56-65 \%$ & Sedang & 0 & 0 \\
\hline 6 & $46-55 \%$ & $\begin{array}{l}\text { Hampir } \\
\text { sedang }\end{array}$ & 1 & 3,33 \\
\hline 7 & $36-45 \%$ & Kurang & 0 & 0 \\
\hline 8 & $26-35 \%$ & $\begin{array}{c}\text { Kurang } \\
\text { sekali }\end{array}$ & 0 & 0 \\
\hline 9 & $16-25 \%$ & Buruk & 0 & 0 \\
\hline 10 & $0-15 \%$ & Buruk sekali & 0 & 0 \\
\hline \multicolumn{3}{|c|}{ Total } & 30 & 100 \\
\hline
\end{tabular}

Rata-rata hitung kemampuan siswa kelas VII1 SMPN 3 Pariaman dalam menulis berita dengan

menggunakan objek langsung indikator I (Struktur Berita) berada pada kualifikasi baik. Nilai yang diperoleh dari penjumlahan seluruh nilai sampel dibagi dengan jumlah sampel.

$$
\begin{aligned}
& \mathrm{M}=\frac{\sum f x}{N} \\
& \mathrm{M}=\frac{2.575}{30} \\
& \mathrm{M}=85,83
\end{aligned}
$$

Tabel 3

Kemampuan Siswa Kelas VII4 SMPN 3 Pariaman dalam Menulis Berita dengan Menggunakan Media Gambar Indikator I

\begin{tabular}{|c|c|c|c|c|}
\hline $\begin{array}{c}\text { N } \\
\text { o }\end{array}$ & $\begin{array}{c}\text { Tingkat } \\
\text { Penguasaa } \\
\mathrm{n}\end{array}$ & Kualifikasi & $\begin{array}{c}\text { Freku } \\
\text { ensi }\end{array}$ & $\begin{array}{c}\text { Persen } \\
\text { tase }\end{array}$ \\
\hline 1 & $96-100 \%$ & Sempurna & 6 & 20 \\
\hline 2 & $86-95 \%$ & Baik sekali & 0 & 0 \\
\hline 3 & $76-85 \%$ & Baik & 0 & 0 \\
\hline 4 & $66-75 \%$ & Cukup & 21 & 70 \\
\hline 5 & $56-65 \%$ & Sedang & 0 & 0 \\
\hline 6 & $46-55 \%$ & $\begin{array}{c}\text { Hampir } \\
\text { sedang }\end{array}$ & 3 & 10 \\
\hline 7 & $36-45 \%$ & Kurang & 0 & 0 \\
\hline 8 & $26-35 \%$ & Kurang sekali & 0 & 0 \\
\hline
\end{tabular}

\begin{tabular}{|c|c|c|c|c|}
\hline 9 & $16-25 \%$ & Buruk & 9 & 30 \\
\hline 10 & $0-15 \%$ & Buruk sekali & 0 & 0 \\
\hline \multicolumn{6}{|c|}{ Total } & 30 & 100 \\
\hline
\end{tabular}

Rata-rata hitung kemampuan siswa kelas $\mathrm{VII}_{4}$ SMPN 3 Pariaman dalam menulis berita dengan menggunakan media gambar indikator I (Struktur Berita) berada pada kualifikasi baik. Nilai yang diperoleh dari penjumlahan seluruh nilai sampel dibagi dengan jumlah sampel.

$$
\begin{aligned}
& \mathrm{M}=\frac{\sum f x}{N} \\
& \mathrm{M}=\frac{2325}{3 \mathrm{D}}, \mathrm{M}=77,5
\end{aligned}
$$

\section{b. Kemampuan Siswa Kelas VII SMPN 3 Pariaman dalam Menulis Berita dengan Menggunakan Objek Langsung Indikator II (Unsur- unsur Berita)}

Data kemampuan siswa kelas VII1 SMPN 3 Pariaman dalam menulis berita dengan menggunakan objek

langsung sebagai media pembelajaran indikator II (Unsurunsur Berita) pada lampiran 10. Berikut ini diuraikan contoh mencari nilai dengan rumus persentase.

$$
\begin{aligned}
\mathrm{N}(01) & =\frac{5 K}{53} \times 5 M a x \\
& =\frac{4}{4} \times 100 \% \\
& =100
\end{aligned}
$$

Hasil analisis dan nilai ratarata tiap sampel dalam indikator II (unsur-unsur berita) dimasukkan ke dalam tabel konveksi skala 10. Data selengkapnya dapat dilihat pada tabel berikut.

Tabel 4

Kemampuan Siswa Kelas VII1 SMPN 3

Pariaman dalam Menulis Berita dengan

Menggunakan Objek Langsung Indikator II 
(Unsur-unsur Berita)

\begin{tabular}{|c|c|c|c|c|}
\hline No & $\begin{array}{c}\text { Tingkat } \\
\text { Penguasaan }\end{array}$ & Kualifikasi & $\begin{array}{c}\text { Freku } \\
\text { ensi }\end{array}$ & $\begin{array}{c}\text { Pers } \\
\text { enta } \\
\text { se }\end{array}$ \\
\hline 1 & $96-100 \%$ & Sempurna & 16 & $\begin{array}{c}53,3 \\
3\end{array}$ \\
\hline 2 & $86-95 \%$ & Baik sekali & 0 & 0 \\
\hline 3 & $76-85 \%$ & Baik & 0 & 0 \\
\hline 4 & $66-75 \%$ & Cukup & 12 & 40 \\
\hline 5 & $56-65 \%$ & Sedang & 0 & 0 \\
\hline 6 & $46-55 \%$ & $\begin{array}{c}\text { Hampir } \\
\text { sedang }\end{array}$ & 2 & 6,67 \\
\hline 7 & $36-45 \%$ & Kurang & 0 & 0 \\
\hline 8 & $26-35 \%$ & $\begin{array}{c}\text { Kurang } \\
\text { sekali }\end{array}$ & 0 & 0 \\
\hline 9 & $16-25 \%$ & Buruk & 0 & 0 \\
\hline 10 & $0-15 \%$ & $\begin{array}{c}\text { Buruk } \\
\text { sekali }\end{array}$ & 0 & 0 \\
\hline \multicolumn{7}{|c|}{ Total } & & 30 & 100 \\
\hline
\end{tabular}

Rata-rata hitung kemampuan siswa kelas VII1 SMPN 3 Pariaman dalam menulis berita dengan menggunakan objek langsung indikator II (Unsur-unsur Berita) berada pada kualifikasi baik. Nilai yang diperoleh dari penjumlahan seluruh nilai sampel dibagi dengan jumlah sampel.

$$
\begin{aligned}
& \mathrm{M}=\frac{\sum f x}{N} \\
& \mathrm{M}=\frac{2.6 \mathrm{DC}}{30} \\
& \mathrm{M}=86,66
\end{aligned}
$$

Tabel 5

Kemampuan Siswa Kelas VII1 SMPN 3 Pariaman dalam Menulis Berita dengan Menggunakan Objek Langsung Indikator II (Unsur-unsur Berita)

\begin{tabular}{|c|c|c|c|c|}
\hline No & $\begin{array}{c}\text { Tingkat } \\
\text { Penguasaan }\end{array}$ & Kualifikasi & $\begin{array}{c}\text { Freku } \\
\text { ensi }\end{array}$ & $\begin{array}{c}\text { Persen } \\
\text { tase }\end{array}$ \\
\hline 1 & $96-100 \%$ & Sempurna & 19 & 63,33 \\
\hline 2 & $86-95 \%$ & Baik sekali & 0 & 0 \\
\hline 3 & $76-85 \%$ & Baik & 0 & 0 \\
\hline 4 & $66-75 \%$ & Cukup & 9 & 30 \\
\hline 5 & $56-65 \%$ & Sedang & 0 & 0 \\
\hline 6 & $46-55 \%$ & $\begin{array}{c}\text { Hampir } \\
\text { sedang }\end{array}$ & 2 & 6,67 \\
\hline 7 & $36-45 \%$ & Kurang & 0 & 0 \\
\hline 8 & $26-35 \%$ & $\begin{array}{c}\text { Kurang } \\
\text { sekali }\end{array}$ & 0 & 0 \\
\hline 9 & $16-25 \%$ & Buruk & 0 & 0 \\
\hline 10 & $0-15 \%$ & $\begin{array}{c}\text { Buruk } \\
\text { sekali }\end{array}$ & 0 & 0 \\
\hline \multicolumn{5}{|c|}{ Total } \\
\hline
\end{tabular}

120 | Jurnal Kredo Vol. 2 No. 1 Oktober 2018
Rata-rata hitung kemampuan siswa kelas $\mathrm{VII}_{4}$ SMPN 3 Pariaman dalam menulis berita dengan menggunakan media gambar indikator II (Unsur-unsur Berita) berada pada kualifikasi baik sekali. Nilai yang diperoleh dari penjumlahan seluruh nilai sampel dibagi dengan jumlah sampel.

$$
\begin{aligned}
& \mathrm{M}=\frac{\sum f x}{N} \\
& \mathrm{M}=\frac{2,675}{3 \mathrm{D}}, \mathrm{M}=89,16
\end{aligned}
$$

\section{c. Kemampuan Siswa Kelas VII1 SMPN 3 Pariaman dalam Menulis Berita dengan Menggunakan Objek Langsung dan Media Gambar Indikator III (Unsur Kebahasaan)}

Data kemampuan siswa kelas VII1 SMPN 3 Pariaman dalam menulis berita dengan menggunakan teknik objek langsung indikator III (Unsur Kebahasaan) pada lampiran 10. Berikut ini diuraikan contoh mencari nilai dengan rumus persentase.

$$
\begin{aligned}
\mathrm{N}(01)= & \frac{S \mathcal{S}}{S J} \times S \operatorname{Max} \\
& =\frac{3}{4} \times 100 \%=75
\end{aligned}
$$

Berdasarkan hasil analisis dan nilai rata-rata tiap sampel dalam indikator III (Unsur Kebahasaan) digambarkan ke dalam tabel konveksi skala 10 dengan data selengkapnya dapat dilihat pada tabel berikut.

Tabel 6

Kemampuan Siswa Kelas VII 1 SMPN 3

Pariaman dalam Menulis Berita dengan Menggunakan Objek Langsung Indikator III (Unsur Kebahasaan)

\begin{tabular}{|c|c|c|c|c|}
\hline $\begin{array}{c}\text { N } \\
\text { o }\end{array}$ & $\begin{array}{c}\text { Tingkat } \\
\text { Pengua } \\
\text { saan }\end{array}$ & $\begin{array}{c}\text { Kualifikas } \\
\text { i }\end{array}$ & $\begin{array}{c}\text { Freku } \\
\text { ensi }\end{array}$ & $\begin{array}{c}\text { Persenta } \\
\text { se }\end{array}$ \\
\hline 1 & $\begin{array}{c}96- \\
100 \%\end{array}$ & Sempurna & 3 & 10 \\
\hline
\end{tabular}




\begin{tabular}{|c|c|c|c|c|}
\hline 2 & $86-95 \%$ & $\begin{array}{c}\text { Baik } \\
\text { sekali }\end{array}$ & 0 & 0 \\
\hline 3 & $76-85 \%$ & Baik & 0 & 0 \\
\hline 4 & $66-75 \%$ & Cukup & 23 & 76,67 \\
\hline 5 & $56-65 \%$ & Sedang & 0 & 0 \\
\hline 6 & $46-55 \%$ & $\begin{array}{c}\text { Hampir } \\
\text { sedang }\end{array}$ & 4 & 13,33 \\
\hline 7 & $36-45 \%$ & Kurang & 0 & 0 \\
\hline 8 & $26-35 \%$ & $\begin{array}{c}\text { Kurang } \\
\text { sekali }\end{array}$ & 0 & 0 \\
\hline 9 & $16-25 \%$ & Buruk & 1 & 2,94 \\
\hline 1 & $0-15 \%$ & $\begin{array}{c}\text { Buruk } \\
\text { sekali }\end{array}$ & 0 & 0 \\
\hline 0 & \multicolumn{5}{|c|}{ Total } & 30 & 100 \\
\hline
\end{tabular}

Rata-rata hitung kemampuan siswa kelas VII1 SMPN 3 Pariaman dalam menulis berita dengan menggunakan objek langsung indikator III (Unsur-Kebahasaan) berada pada kualifikasi cukup. Nilai yang diperoleh dari penjumlahan seluruh nilai sampel dibagi dengan jumlah sampel.

$$
\begin{aligned}
& \mathrm{M}=\frac{\sum f x}{N} \\
& \mathrm{M}=\frac{2.225}{3 \mathrm{D}} \\
& \mathrm{M}=74,16
\end{aligned}
$$

Tabel 7

Kemampuan Siswa Kelas VII4 SMPN 3 Pariaman dalam Menulis Berita

\begin{tabular}{|c|c|c|c|c|}
\hline No & $\begin{array}{c}\text { Tingkat } \\
\text { Penguasaan }\end{array}$ & Kualifikasi & $\begin{array}{c}\text { Frekuen } \\
\text { si }\end{array}$ & $\begin{array}{c}\text { Persen } \\
\text { tase }\end{array}$ \\
\hline 1 & $96-100 \%$ & Sempurna & 2 & 6,67 \\
\hline 2 & $86-95 \%$ & Baik sekali & 0 & 0 \\
\hline 3 & $76-85 \%$ & Baik & 0 & 0 \\
\hline 4 & $66-75 \%$ & Cukup & 18 & 60 \\
\hline 5 & $56-65 \%$ & Sedang & 0 & 0 \\
\hline 6 & $46-55 \%$ & $\begin{array}{l}\text { Hampir } \\
\text { sedang }\end{array}$ & 10 & 33,33 \\
\hline 7 & $36-45 \%$ & Kurang & 0 & 0 \\
\hline 8 & $26-35 \%$ & $\begin{array}{c}\text { Kurang } \\
\text { sekali }\end{array}$ & 0 & 0 \\
\hline 9 & $16-25 \%$ & Buruk & 0 & 0 \\
\hline 10 & $0-15 \%$ & Buruk sekali & 0 & 0 \\
\hline \multicolumn{3}{|c|}{ Total } & 30 & 100 \\
\hline
\end{tabular}
dengan Menggunakan Media Gambar Indikator III (Unsur Kebahasaan)

Rata-rata hitung kemampuan siswa kelas VII4 SMPN 3 Pariaman dalam menulis berita dengan menggunakan teknik gambar indikator III (Unsur Kebahasaan) berada pada kualifikasi cukup. Nilai yang diperoleh dari penjumlahan seluruh nilai sampel dibagi dengan jumlah sampel.

$$
\begin{aligned}
& \mathrm{M}=\frac{\sum f x}{N} \\
& \mathrm{M}=\frac{2.050}{30} \\
& \mathrm{M}=68,33
\end{aligned}
$$

\begin{tabular}{|c|c|c|c|c|}
\hline $\begin{array}{l}\mathbf{N} \\
\mathbf{o}\end{array}$ & $\begin{array}{c}\text { Kode } \\
\text { Sampe } \\
1 \\
\end{array}$ & $\begin{array}{c}\text { Sko } \\
\mathbf{r}\end{array}$ & Nilai & $\begin{array}{c}\text { Kualifika } \\
\text { si }\end{array}$ \\
\hline 1 & 2 & 3 & 4 & 5 \\
\hline 1 & 01 & 11 & 91,66 & $\begin{array}{c}\text { Baik } \\
\text { Sekali }\end{array}$ \\
\hline 2 & 02 & 8 & 66,66 & Cukup \\
\hline 3 & 03 & 9 & 75 & Cukup \\
\hline 4 & 04 & 11 & 91,66 & $\begin{array}{c}\text { Baik } \\
\text { Sekali }\end{array}$ \\
\hline 5 & 05 & 10 & 83,33 & Baik \\
\hline 6 & 06 & 8 & 66,66 & Cukup \\
\hline 7 & 07 & 8 & 66,66 & Cukup \\
\hline 8 & 08 & 10 & 83,33 & Baik \\
\hline 9 & 09 & 10 & 83,33 & Baik \\
\hline 10 & 10 & 11 & 91,66 & $\begin{array}{c}\text { Baik } \\
\text { Sekali }\end{array}$ \\
\hline 11 & 11 & 11 & 91,66 & $\begin{array}{c}\text { Baik } \\
\text { Sekali }\end{array}$ \\
\hline 12 & 12 & 11 & 91,66 & $\begin{array}{c}\text { Baik } \\
\text { Sekali }\end{array}$ \\
\hline 13 & 13 & 9 & 75 & Cukup \\
\hline 14 & 14 & 11 & 91,66 & $\begin{array}{c}\text { Baik } \\
\text { Sekali }\end{array}$ \\
\hline 15 & 15 & 11 & 91,66 & $\begin{array}{c}\text { Baik } \\
\text { Sekali }\end{array}$ \\
\hline 16 & 16 & 9 & 75 & Cukup \\
\hline 17 & 17 & 11 & 91,66 & $\begin{array}{c}\text { Baik } \\
\text { Sekali }\end{array}$ \\
\hline 18 & 18 & 7 & 58,33 & Sedang \\
\hline 19 & 19 & 11 & 91,66 & $\begin{array}{c}\text { Baik } \\
\text { Sekali }\end{array}$ \\
\hline 20 & 20 & 10 & 83,33 & Baik \\
\hline 21 & 21 & 8 & 66,66 & Cukup \\
\hline 22 & 22 & 9 & 75 & Cukup \\
\hline 23 & 23 & 10 & 83,33 & Baik \\
\hline 24 & 24 & 11 & 91,66 & $\begin{array}{c}\text { Baik } \\
\text { Sekali }\end{array}$ \\
\hline 25 & 25 & 11 & 91,66 & $\begin{array}{c}\text { Baik } \\
\text { Sekali }\end{array}$ \\
\hline 26 & 26 & 11 & 91,66 & $\begin{array}{c}\text { Baik } \\
\text { Sekali }\end{array}$ \\
\hline 27 & 27 & 9 & 75 & Cukup \\
\hline
\end{tabular}

Tabel 8

Data Umum Tes Akhir Skor Nilai dan Kualifikasi Nilai Menulis dengan Menggunakan Objek Langsung Siswa Kelas VII 1 SMPN 3 Pariaman 


\begin{tabular}{|c|c|c|c|c|}
\hline 28 & 28 & 8 & 66,66 & Sedang \\
\hline 29 & 29 & 10 & 83,33 & Cukup \\
\hline 30 & 30 & 10 & 83,33 & Cukup \\
\hline \multicolumn{3}{|c|}{ Jumlah } & $\begin{array}{c}2.433,1 \\
9\end{array}$ & Baik \\
\hline
\end{tabular}

Tabel 8

Data Umum Tes Akhir Skor Nilai dan

Kualifikasi Nilai Menulis dengan

Menggunakan Media Gambar Siswa

Kelas VII4 SMPN 3 Pariaman

\begin{tabular}{|c|c|c|c|c|}
\hline No & $\begin{array}{c}\text { Kode } \\
\text { Sampel }\end{array}$ & $\begin{array}{c}\text { Sko } \\
\text { r }\end{array}$ & Nilai & $\begin{array}{c}\text { Kualifika } \\
\text { si }\end{array}$ \\
\hline 1 & 2 & 3 & 4 & 5 \\
\hline 1 & 01 & 10 & 83,33 & Baik \\
\hline 2 & 02 & 11 & 91,66 & $\begin{array}{c}\text { Baik } \\
\text { Sekali }\end{array}$ \\
\hline 3 & 03 & 9 & 75 & Cukup \\
\hline 4 & 04 & 7 & 58,33 & $\begin{array}{l}\text { Hampir } \\
\text { Sedang }\end{array}$ \\
\hline 5 & 05 & 11 & 91,66 & $\begin{array}{c}\text { Baik } \\
\text { Sekali }\end{array}$ \\
\hline 6 & 06 & 8 & 66,66 & Cukup \\
\hline 7 & 07 & 9 & 75 & Cukup \\
\hline 8 & 08 & 11 & 91,66 & $\begin{array}{c}\text { Baik } \\
\text { Sekali }\end{array}$ \\
\hline 9 & 09 & 10 & 83,33 & Baik \\
\hline 10 & 10 & 8 & 66,66 & Sedang \\
\hline 11 & 11 & 11 & 91,66 & $\begin{array}{c}\text { Baik } \\
\text { Sekali }\end{array}$ \\
\hline 12 & 12 & 9 & 75 & Cukup \\
\hline 13 & 13 & 9 & 75 & Cukup \\
\hline 14 & 14 & 10 & 83,33 & Baik \\
\hline 15 & 15 & 8 & 66,66 & Sedang \\
\hline 16 & 16 & 10 & 83,33 & Baik \\
\hline 17 & 17 & 8 & 66,66 & Sedang \\
\hline 18 & 18 & 8 & 66,66 & Cukup \\
\hline 19 & 19 & 10 & 83,33 & Baik \\
\hline 20 & 20 & 10 & 83,33 & Cukup \\
\hline 21 & 21 & 11 & 91,66 & $\begin{array}{c}\text { Baik } \\
\text { Sekali }\end{array}$ \\
\hline 22 & 22 & 10 & 83,33 & Baik \\
\hline 23 & 23 & 10 & 83,33 & Baik \\
\hline 24 & 24 & 9 & 75 & Cukup \\
\hline 25 & 25 & 7 & 58,33 & Sedang \\
\hline 26 & 26 & 7 & 58,33 & Sedang \\
\hline 27 & 27 & 9 & 75 & Cukup \\
\hline 28 & 28 & 10 & 83,33 & Baik \\
\hline 29 & 29 & 7 & 58,33 & Sedang \\
\hline 30 & 30 & 9 & 75 & Cukup \\
\hline \multicolumn{3}{|c|}{ Jumlah } & $\begin{array}{c}2.282 \\
8\end{array}$ & Baik \\
\hline
\end{tabular}

Untuk mengetahui perbedaan kemampuan siswa kelas VII SMPN 3 Pariaman dengan menggunakan media gambar dan objek langsung dapat dilihat dari rincian urutan kerja berikut ini. Tahap selanjutnya setelah nilai rata-rata hasil kemampuan kelas eksperimen dan kontrol diperoleh, kedua data tersebut dilihat apakah ada perbedaan hasil akhirnya. Jika skala kemampuan siswa kelas eksperimen dan kelas kontrol diperkirakan hasilnya ada perbedaan dari perlakuan eksperimen objek langsung dan media gambar pada kelas kontrol. Sehingga untuk melihat keberartian perbedaan antara kedua kelas dengan dua perlakuan berbeda tersebut maka dilaksanakan uji kesamaan dua rata-rata atau uji-t dengan rumus:

$$
\mathrm{t}=\frac{\overline{X_{1}}-\overline{X_{2}}}{\sqrt[s]{\frac{1}{\pi 1}+\frac{1}{\pi \bar{z}}}}
$$

Sebelum uji-t dilaksanakan, terlebih dahulu ditentukan apakah sampel diperoleh dari populasi berdistribusi normal dan kedua sampel mempunyai varians yang homogen.

\section{Uji Homogenitas}

Kelas Eksperimen

\section{Kontrol}

$\mathrm{n}=30, \quad \mathrm{~S}_{1}=10,65$

10,66

$\bar{X}=81,11 s_{1}^{2}=113,42$

\section{Kelas}

113,63

$\mathrm{F}=\frac{s_{1}^{2}}{s_{1}^{2}}=\frac{113,63}{113, A 2}=1,00$

$\mathrm{dk}_{1}=\mathrm{n}_{1}-1$

$\mathrm{dk}_{2}=\mathrm{n}_{2}-1$

Dari data di atas dengan taraf kepercayaan $95 \%$ atau $a=0,05 \mathrm{dan} \mathrm{dk}=$ (30+30-2) maka $\mathrm{F}_{\text {tabel }}$ adalah:

$\mathrm{F}_{\text {tabel }}=\mathrm{t}_{(0,95)(30+30)}$

$$
=1,67
$$

Jadi, $F_{\text {hitung }}<\mathrm{F}_{\text {tabel }}(1,00<1,67$ maka homogen)

Untuk menentukan besarnya thitung kemampuan siswa kelas VII SMPN 3 Pariaman dengan menggunakan media gambar dan objek langsung, langkah yang dilakukan sebagai berikut. Pertama, mencari rata-rata hitung kelas eksperimen dan kelas kontrol. Rata- 
rata hitung kemampuan menulis berita siswa kelas VII1 SMPN 3 Pariaman dengan menggunakan objek langsung adalah 81,11 dan Rata-rata hitung kemampuan menulis berita siswa kelas VII4 SMPN 3 Pariaman dengan menggunakan teknik gambar adalah 76. Kedua, menentukan simpangan baku data tersebut. Simpangan baku untuk siswa kelas VII SMPN 3 Pariaman dengan menggunakan teknik objek langsung adalah 10,65 dan Simpangan baku untuk siswa kelas VII SMPN 3 Pariaman dengan menggunakan teknik gambar adalah 10,66, untuk lebih rincinya dapat diperhatikan pada tabel berikut.

Tabel 9

Nilai Rata-rata, Simpangan Baku, dan Variansi Kelas Sampel

\begin{tabular}{|l|c|c|c|c|}
\hline \multicolumn{1}{|c|}{ Kelas } & $(\mathrm{X})$ & $\mathrm{N}$ & $(\mathrm{S})$ & $\left(\mathrm{S}^{2)}\right.$ \\
\hline Eksperimen & 81,11 & 30 & 10,65 & 12,08 \\
\hline Kontrol & 76 & 30 & 10,66 & \\
\hline
\end{tabular}

Ketiga, menentukan besarnya simpangan baku gabungan $\left(\mathrm{S}^{2}\right)$ dengan menggunakan rumus sebagai berikut.

$$
\mathrm{S}^{2}=\sqrt{\frac{\left(\frac{\left.n_{1}-1\right) S^{2}+\left(n_{2}-1\right) S^{2}}{n_{1}+n_{2}-2}\right.}{\sqrt{\frac{(30-1) 10,65^{2}+(30-1) 10,66^{2}}{30+30-2}}}}
$$

$$
\sqrt{\frac{(29) 113,42+(29) 113,63}{58}}=\sqrt{\frac{3289,25+3295,43}{58}}
$$

$$
=10,65
$$

thitung $=$

$$
\begin{aligned}
& \frac{\bar{X}_{1}-\bar{X}_{2}}{S \sqrt{\frac{1}{n_{1}}+\frac{1}{n_{2}}}}=\frac{81,11-76}{10,65 \sqrt{\frac{1}{30}+\frac{1}{30}}}=\frac{5,11}{11,30 \sqrt{0,03+0,03}} \\
& =\frac{5,11}{2,60}=1,96
\end{aligned}
$$

Dengan perolehan $\mathrm{t}_{\text {tabel }}=\mathrm{t}(1-a)\left(\mathrm{n}_{1}+\mathrm{n}_{2}\right)$

$$
=\mathrm{t}(0,95)(60)
$$

$$
=1,67
$$

Setelah dilakukan uji-t pada taraf nyata 0,05 diperoleh $t_{\text {hitung }}=$ 1,96 dan $\mathrm{t}_{\text {tabel }} 1,67$. Jadi, $\mathrm{t}_{\text {hitung }}>\mathrm{t}_{\text {tabel }}$, sehingga dapat disimpulkan bahwa $\mathrm{H}_{1}$ diterima, karena terdapat perbedaan dari hasil belajar siswa kelas $\mathrm{VII}_{1}$ dengan $\mathrm{VII}_{4}$. Jadi, setelah guru mengadakan pembelajaran di kedua kelas dan melakukan tes unjuk kerja menulis berita dengan media gambar pada kelas $\mathrm{VII}_{4}$ dan objek langsung pada kelas $\mathrm{VII}_{1}$ maka hasil akhirnya hasil menulis berita siswa dengan objek langsung lebih berhasil dibandingakan dengan siswa yang menggunakan media gambar. Hal ini disebabkan, objek langsung mampu meningkatkan kemampuan menulis berita dengan menyaksikan suatu peristiwa atau kejadian secara langsung. Untuk lebih rincinya dapat dilihat dalam tabel berikut.

Tabel 10

Uji Kesamaan Dua Rata-rata atau Uji-t

\begin{tabular}{|l|c|c|c|c|c|}
\hline \multicolumn{1}{|c|}{ Kelas } & $\mathrm{N}$ & $\mathrm{X}$ & $\mathrm{S}$ & $\mathrm{t}_{\text {hitung }}$ & $\mathrm{t}_{\text {tabel }}$ \\
\cline { 1 - 4 } Eksperimen & 30 & 81,11 & 10,65 & \multirow{2}{*}{1,96} & 1,67 \\
\hline Kontrol & 30 & 76 & 10,66 & & \\
\hline
\end{tabular}


Berdasarkan uji-t pada taraf nyata (a) 0,05 diperoleh $t_{\text {hitung }}=$ 1,96 dan $\mathrm{t}_{\text {tabel }}$ dengan $\mathrm{dk}=\mathrm{n}_{1}+\mathrm{n}_{2}$ dengan peluang $(1-a)$. Untuk hargaharga t lainnya HO ditolak. Harga $t_{\text {hitung }}$ yang diperoleh tidak berada dalam daerah penerimaan $\mathrm{H} 0$ sehingga $\mathrm{H}_{1}$ diterima. Oleh karena itu, kedua sampel memiliki perbedaan dari media pembelajaran yang digunakan dalam menulis berita. Dapat disimpulkan bahwa setelah guru mengadakan pembelajaran di kedua kelas dan melakukan tes unjuk kerja menulis berita dengan media gambar pada kelas $\mathrm{VII}_{4}$ dan objek langsung pada kelas $\mathrm{VII}_{1}$ maka hasil akhirnya hasil menulis berita siswa dengan objek langsung sebagai media pembelajaran lebih berhasil dibandingkan dengan siswa yang menggunakan media gambar. Hal ini disebabkan, objek langsung mampu meningkatkan kemampuan menulis berita dengan menyaksikan suatu peristiwa atau kejadian secara langsung.

\section{SIMPULAN}

Berdasarkan penghitungan
atau analisis data yang telah
dilaksanakan mengenai kemampuan
siswa kelas VII SMPN 3 Pariaman

dalam menulis berita dengan menggunkan media gambar dan objek langsung diperoleh tiga kesimpulan. Pertama, kemampuan siswa kelas eksperimen dengan menggunakan objek langsung berada pada kualifikasi baik (B) dengan rata-rata hitung 81,11. Kedua, kemampuan siswa kelas kontrol dengan menggunakan media gambar berada pada kualifikasi baik (B) dengan rata-rata hitung 76. Ketiga, setelah dilakukan uji-t diperoleh $\mathrm{t}_{\text {hitung }}=1,96$ dan $\mathrm{t}_{\text {tabel }}=1,67$ yaitu $\mathrm{t}_{\mathrm{h}}>$ $\mathrm{t}_{\mathrm{t}}$, maka $\mathrm{H}_{1}$ diterima. Jadi, setelah guru mengadakan pembelajaran di kedua kelas dan melakukan tes unjuk kerja menulis berita dengan media gambar pada kelas $\mathrm{VII}_{4}$ dan objek langsung pada kelas VIII maka hasil akhirnya hasil menulis berita siswa dengan objek langsung lebih berhasil dibandingkan dengan siswa yang menggunakan media gambar. Hal ini disebabkan, objek langsung lebih mampu meningkatkan kemampuan menulis berita siswa, karena menyaksikan suatu peristiwa atau kejadian secara langsung, siswa menjadi termotivasi untuk menulis berita yang disaksikan dan didengarkan secara langsung.

\section{DAFTAR PUSTAKA}

Abdurahman dan Ellya Ratna. 2003. "Evaluasi Pembelajaran Bahasa dan Sastra Indonesia". (Buku Ajar). Padang: FBSS UNP.

Arif, S. Sadiman. 2006. Media Pendidikan, Pengertian, Pengembangan dan Pemanfaatannya. Jakarta: PT. Raja Grafindo Persada.

Assegaf. 1982. Jurnalistik Masa Kini. Jakarta: Ghalia Indonesia.

Hermawan, dkk. 2004. Ragam Menulis. Yogyakarta: UGM Press.

124 | Jurnal Kredo

Vol. 2 No. 1 Oktober 2018 
Kusumaningrat, Hikmat dan Purnama Kusumaningrat. 2005. Jurnalistik Teori dan Praktik. Bandung: PT. Remaja Rosdakarya.

Sanjaya, Wina. 2008. Strategi Pembelajaran. Jakarta: Kencana Prenada Media Group.

Semi, Atar. 2007. Dasar-dasar Keterampilan Menulis. Bandung: PT. Angkasa.

Semi, Atar. 2009. Menulis Efektif. Padang: UNP Press.

Subana, M dan Sunarti. 2009. Strategi Belajar Mengajar Bahasa Indonesia. Jakarta: Pustaka Setia.

Sudjana. 2005. Metoda Statistika. Bandung: Tarsito Bandung.

Sudjana, Nana dan Ibrahim. 2010. Penelitian dan Penilaian Pendidikan. Bandung: Sinar Baru Alegensindo.

Suryabrata, Sumadi. 2004. Metodologi Penelitian. Jakarta: PT. RajaGrafindo Persada.

Tarigan, Hendry Guntur. 2008. Menulis Sebagai Suatu Keterampilan Berbahasa. Bandung: PT. Angkasa. 